UDC 792.011.4(536.8)

DOI: $10.31866 / 2616-759 x .2 .2018 .153137$

\title{
Al-Anezi Ali, \\ $\mathrm{PhD}$ in criticism and literature, Assistant Professor, Higher Institute of Dramatic Arts Criticism Division, Kuwait City, Kuwait E-mail: aliali2222@hotmail.com ORCID: https://orcid.org/0000-0001-5405-7027
}

\section{SA'AD AL-FARAJ'S DRAMA \\ IN THE CONTEXT OF THEATRICAL AFFAIRS' DEVELOPMENT IN KUWAIT IN THE SECOND HALF OF THE TWENTIETH CENTURY}

The purpose of the article is to study the activities of theaters in Kuwait in general and the interpretation of their contemporary Arabic drama on their scenes in particular against the backdrop of political events in the Middle East in the second half of the twentieth century. The author focuses on the creative work of Sa'ada al-Faraj, a famous actor, theatrical figure, playwright, and public figure in Kuwait. The researcher focuses on political circumstances that have brought about the actualization of individual topics that affect Sa'ad al-Faraj's plays, analyzes how the confrontation between Israel and the Arab world, the policies of Egyptian President Gamal Abdel Nasser influenced the speculations of the creative intelligentsia of Kuwait. Essential for the author of the article is the problem of political censorship in modern Kuwait, which caused the short-lived scenic life of a number of plays Saad al-Faraj. Much of the intelligence is devoted to the peculiarities of poetry in drama Sad al-Faraj. In the time of his creative establishment, the artist was under the significant influence of European innovative movements in the twentieth century, and this greatly influenced the artistic image of his texts. In the center of the researcher's attention is a play by Sa'ad al-Faraj «Tradition is another nature», which clearly show the receptions of the epic theater Bertolt Brecht. The methodology of the research is to apply political science in order to expedite the full disclosure of the public context in the activities of Kuwait theaters and the works of playwright Sa'ad al-Faraj. Introducing the work of the Kuwaiti playwright in the world context, the author relies on system-structural and comparative methods. Essential in considering a particular dramatic work was the use of theatrical-critical analysis. The novelty of the work. For the first time, comprehensively and using political methodology and drawing on an art-study analysis, the activities of theaters in Kuwait in the second half of the twentieth century have been explored. The scientific circle introduces important information about the creative work of Sa'ad al-Faraj, which is carried out an art-study analysis of his play «Tradition is another nature». Conclusions. Summarizing the above mentioned in Kuwait, all the major theatres were under the supervision of the governmental censor, which, according to al-Faraj, found it desirable to use the theatre only to disseminate culture 'by presenting random and irrelevant examples from the repertoire of world theatre'.

Key words: arabic drama; muslim worlds; Kuwaiti independence; political circumstances. 
Relevance of research topic. The name of the Kuwaiti dramatist Saad al-Faraj is virtually unknown to Western readers and theatregoers despite his reputation among his own people; none of his works has been translated into English. It must also be admitted that even in the Arab world al-Faraj's fame rests not so much on his plays as on his well-documented acting carrier and struggle with censorship. ${ }^{1}$ This contradiction is attributable to two factors: as the scholar Ali al Souleman points out, ${ }^{2}$ theatre in the Arab world and elsewhere has lost its dominance as an art form as film, television and computers have gained in status; and surprisingly little attention is devoted to theatre studies by Arab academics. Thus al-Faraj the dramatist has been eclipsed by al-Faraj the celebrity. Given this situation, it is not surprising that alFaraj's fame has not spread beyond the Arab world. Moreover, it is not only Arabic drama that has failed to penetrate the West; even though the complex politics of the Middle East have become a matter of universal concern after the events of 11 September 2001, the literature of the Arabs has received scant attention outside the Arab and Muslim worlds - the two great exceptions being the collection of tales known as the Thousand and One Nights, and the Holy Quran, Islam's sacred text and the Arabs' cultural yardstick. As M. M. Badawi has noted, this neglect is particularly true of modern practitioners: 'Despite the fact that the Nobel Prize for literature was awarded to the Egyptian novelist Naguib Mahfouz in 1988, modern Arabic literature is hardly known outside a narrow circle of academic specialists'. ${ }^{3}$

The Arabic word for literature is adab (literally, manners) and more or less covers the field denoted by the European term 'belles-letters', though including biography and travel writing. Modern Arabic literature to have began with Napoleon's invasion of Egypt in 1798, which disrupted «the inward-looking and exhausted complacency into which Arab culture had fallen during the decline of the Ottoman Empire», ${ }^{4}$ and which paved the way for future developments. Although much is known about early and medieval Arabic literature there is a surprising dearth of information about the pre-modern period (thirteenth to eighteenth century) which makes it difficult to assess the nature of the changes which took place in the nineteenth. The period between the end of the Middle Ages and 1800, which produced hardly any Arabic literature of distinction, is known as the Asr al-Inhitat (The Age of Depression) ${ }^{5}$ Nevertheless it is clear the modernisation was marked by both the encounter with the West and by a revival of the heritage of the past, and that drama was particularly slow to develop. ${ }^{6}$ The two aspects of modernisation can be seen in the work of most Arab dramatists and are present, in varying degrees, in GCC playwright's plays.

\footnotetext{
${ }^{1}$ Saad al-Faraj was a Kuwaiti actor and playwright who, along with his contemporary Abdul Hussain Abdul Rida dominated the Kuwaiti stage of the mid-20th century. He also wrote 21 plays throughout his career. Late in his career, he had considerable success in television roles.

${ }^{2}$ See Ali al Souleman, From Staging the World to Staging the Self: Sa'dall ah Wann us and the Question of Theatre, Ph.D. thesis (Oxford University, 2005), p.11.

${ }^{3}$ M. M. Badawi, A Short History of Modern Arabic Literature (New York: Oxford University Press, 1993), p. preface.

${ }^{4}$ M. M. Badawi, A Short History of Modern Arabic Literature (New York: Oxford University Press, 1993), p.1.

${ }^{5}$ Trevor Mostyn, Censorship on Islamic Societies (London: Saqi Books, 2002), p.76.

${ }^{6}$ Roger Allen, An Introduction To Arabic Literature (United Kingdom: Cambridge University Press, 2000), p.3
} 
Analysis of the previous researches and publications. This problem has drawn much attention in books to understand Arabic literature and modern Arabic drama in particular, by presenting the career of Saad al-Faraj as a dramatist and analysing his most important work, i. e. Hatha Sefoh-Custom is Another Nature (1987). Saad alFaraj. Fintas is a tranquil village in the South of Kuwait province, situated on a plateau with a commanding view of the Arabian Gulf coast. It was here that al-Faraj was born on 11 January 1938; al-Faraj's generation was the first to be able to benefit from the new educational opportunities and his parents encouraged his studies. Although al-Faraj's parents were by no means destitute, it should be remembered that they, and all the other peasants in Fintas and beyond, were living under an inherited semi-feudal system which the British Empire had done nothing to reform.

The purpose of the article is to study the activities of theaters in Kuwait in general and the interpretation of their contemporary Arabic drama on their scenes in particular against the backdrop of political events in the Middle East in the second half of the twentieth century.

The excesses of the feudal landlords who were recorded in living memory, and alFaraj's grandfathers would apparently tell him tales of the cruelty of life. ${ }^{7}$ The lords of Fintas owned over 10 square kilometres of land and had ruled the district for more than two hundred years. It seems that al-Faraj himself never witnessed any such incidents, but his elders' bitter stories seem to have made an indelible impression on him. ${ }^{8}$ The power of the feudal dynasties would not be broken until 1961, the first year of the independence of Kuwait, which marked the first real attempt at land reform in Kuwait. al-Faraj certainly did witness how hard the life of the peasants could be, and he also witnessed the ways in which they alleviated the harshness of their existence. One of these was the evening meeting, at which the farmers would enact impromptu dramas full of black humour and striking characters, which commented on the difficulties of their lives and their daily concerns.

Thus Al-Faraj's childhood was spent not only in academic study but, perhaps more importantly, in the study of his own people. He later spoke of the purity of the peasants' community, far removed from the contamination of modern civilisation and its materialistic complexities: 'The distinctive thing is how those people lived, helping each other in the face of life's hardships. The richest people were the poorest because of the extent of the support and charity they offered. The rich would give the poor families crops from their fields. So there was a spirit of love and solidarity among them' ${ }^{9}$ His primary school teacher recalled that even as a boy Al-Faraj was concerned with the plight of the people of his village. He remarked that he was 'a serious nationalist and brighter than the other children of his age'. ${ }^{10}$ As well as attending the evening meetings, Al-Faraj and his young friends would sit among his elders as they discussed their affairs, and he also began to acquire a little knowledge of his heritage. Guests of his parents would tell the children stories, sometimes from the folk tradition; religious men would discourse on the Quran; and there might be readings from the Al-Zeir Abu layla almuhalhil Adi ibn Rabia', the pre-Islamic epic

\footnotetext{
${ }^{7}$ Unpublished interview with the Kuwaiti playwright Saad al-Faraj in 11-5-2016

${ }^{8}$ Ibid.

${ }^{9}$ Ibid.

${ }^{10}$ Ibid.
} 
of heroism and valiant deeds. These early experiences were to bear fruit in his work, particularly in his incorporation of folk elements into the plays of his middle period. However, once he had distanced himself from his home village and experienced life in London (1969-1970) and Los Angeles (1972-1974), ${ }^{11}$ his attitudes to the world of the commoners and lower class became problematic. In 1969, having gained his Baccalaureate, he decided to pursue his studies in the virtual capital of Europe. Al-Faraj chose to study in London, but as yet he had his own intention of becoming a dramatist; he travelled to England capital and took up a scholarship in media.

It was during his stay in England, however, that he became increasingly interested in serious theatre, devouring works by European and American playwrights, including the Existentialists and practitioners of the 'Theatre of the Absurd'; he was also drawn to read critical literature on the theatre. It was at this time that Al-Faraj became a reader of Al-Adab, the most influential Arab literary journal, which translated and published works by Camus and Sartre. In the late 1960s, the magazine had a great impact on Al-Faraj' approach to theatre, and the influence of modern theatre is apparent in some of his early plays. ${ }^{12}$ It should also be noted that, however, the case of Al-Faraj and other Arab 'Twentieth-century playwrights' is a complex one, and although Al-Faraj was influenced by Twentieth-century theatre and that his work contains Expressionist and Symbolist elements. . The Syrian critic and novelist Nadim Mualla (1948-2014), who spent most of his adult life in Syria, remarked, is surely right to adopt a simpler view of these works: 'Though often said to have been influenced by Twentieth-century theatre, his works are focussed on the «social condition» of the individual, rather than the issues of the 'self' that mark modern literature'. ${ }^{13}$

After gaining his degree in 1974, Al-Faraj moved to Kuwait, where he served in the Ministry of information and became head of the drama division of Kuwait TV. He had begun while a student in London and Los Angeles to write plays somewhat on the model of Berthold Brecht's 'political theatre', and he continued to do so in Kuwait. In his homeland, al-Faraj pursued his study of theatre, broadening his reading and acquainting himself with various schools. ${ }^{14} \mathrm{Of}$ particular interest is his interview with Kuwait TV, He was asked to advise Arab dramatists on creating an Arab theatre in the absence of a strong indigenous modern tradition, al-Faraj, replied that the attack on the abuse of authority could be based on the implied criticism of the class conflict system found in the folkloric tradition. He suggested it would be a mistake to attempt to create theatre on the Arab models, which were inflexible and stifled spontaneity. Kuwaiti dramatists should therefore seek to make a fresh start, inspired by a modern collective enthusiasm. ${ }^{15}$

Years of study was to bear fruit in the following years; but Al-Faraj's theatre were suddenly and rudely interrupted by the catastrophe of the Six-Day War of June 1967, and the Ramadan War of October 1973. The two wars were for him, as for most Arabs, a profound shock. It was 'a turning point in every respect, a disaster that

\footnotetext{
${ }^{11}$ Saad al-Faraj studied media in London, and theatre studies in Los Angeles.

${ }^{12}$ See al-Faraj's play, Kuwait in 2000.

${ }^{13}$ Unpublished interview with the Syrian critic Dr. Nadim Mua'ala in 12-4-2013.

${ }^{14}$ Unpublished interview with the Kuwaiti playwright Saad al-Faraj in 11-5-2016

${ }^{15}$ Ibid.
} 
destroyed established ways of thinking, especially ideas about the theatre. The wars had a clear impact on the public in general, and on educated men in particular, as to their beliefs, behaviour and thinking [...] only when the storm subsided was reason able to contemplate the disaster' ${ }^{16}$ As for al-Faraj himself, the memory of the shock was still vivid even as he approached his declining years. In an interview made by his friend and collaborator Ali al-'Awadi, he recalled:

My ideology is Nasserist. When Nasser acknowledged the 1967 defeat and we knew for certain it was true, I felt that this was the end. Everything connecting me to life, to being itself, had collapsed. ${ }^{17}$

Highlighting the topically of the research. There is a great importance of the fact that the catastrophes of the late sixties marked a turning-point in Al-Faraj's life and work, and led to the writing of Hat al-Tair Tar al-Tair (1971), which as well as being written expressly for the stage by his comrade Abdul Amir al-Turki and alFaraj as the leading character, was the first overtly 'political' play about class conflict, and the first notable success, to be vetoed while performing. It will be useful here to provide a brief account of the developments that had led to the defeat. As a child Al-Faraj had imbibed tales of colonial misrule and the cruelty of feudal landlords in Arab World, as a young adults al-Turki and al-Faraj had witnessed the founding and dissolution of the UAR, and like all Arabs they were dismayed by the continuing existence and growing strength of Israel. It seems right, therefore, to give some account of the world he had grown up in.

The main material presentation. The last two major attempts of Britain and France, the two former colonial powers, to reassert their position in Arab countries were the Suez crisis of 1956 and the Algerian war (the 'War of a Million Martyrs') of 1954-62. British withdrawal from Palestine had led to the creation of the State of Israel, a major defeat for the Arabs. Arab societies were in the process of rapid change, and the dominant idea of the 1940s and 1950s was that of a nationalism not of individual countries but of the Arab peoples as a whole. This idea was embodied for a time in the personality of Nasser, the ruler of Egypt, whose major achievements, such as the nationalisation of the Suez Canal in 1956 and the establishment of the United Arab Republic between Egypt and Syria (1958-61), were seen as triumphs in the Arab world and led to significant changes in local and international alignments. ${ }^{18}$ The defeat of Egypt, Syria and Jordan at the hands of Israel in 1967, however, halted the advance of Arab nationalism and opened a period of disunity and increasing dependency on one or another of the superpowers, with the USA in the ascendant. ${ }^{19}$

\footnotetext{
${ }^{16}$ Al-Tahir Ahmid, The War of June 1967, Issue 30 (Cairo: Al-Ahram Centre for Translation and Publishing, 1997), p.88.

17 Ali Husain al-Awadi, 'Interview with Saad al-Faraj', al-Taleea News Paper, 8-7-2015, http://altaleea.com/?p=13344seen on 10/10/2017.

${ }_{18}$ Roger Allen, An Introduction to Arabic Literature (United Kingdom: Cambridge University Press, 2000), p.49.

${ }^{19}$ Albert Hourani, A History of the Arab Peoples (London: Faber and Faber, 2002), p.351.
} 
Al-Faraj placed a high value on Arab unity, and like many Arabs in general and Kuwaitis in particular, he welcomed the establishment of any Arab unity. Yet, Nasser's attempt to rule UAR antagonised the Arabs, however, and the UAR was dissolved in 1961 after a military coup. Al-Faraj detested the Arab authoritarian regimes and all its successors without exception. He attacked the Arab dictatorships in play after play, sometimes managing to avoid the censors. He appears never to have been in personal danger for a variety of reasons, but a number of his plays with al-Turki were banned, mostly because of their political stance. The real beneficiary of the triumph of nationalism, however, was not the Arab peoples, but the state - those who controlled the government and those in the military and civil service through whom its power was exercised. The most spectacular example of state intervention, however, was given not by industry but by reform of the system of landownership. This had the greatest political and social importance, because most of the population of the Arab countries still lived in the countryside and also because almost everywhere the large landowners formed the most powerful class, possessing the most influence over the government and the most capital. As for oil, Al-Faraj was always concerned that oil wealth was not used to benefit the people or as a weapon against the Arab nation's enemies. His attitude to the oil-rich state is expressed (somewhat obscurely, it must be admitted) in the extraordinary imagery of the central scenes of Kuwait Sanat 2000 (1965) and Madarib Bani Naft (1990) where the male characters grow a corrupted mentality. Everywhere cities grew, especially Hawally and Nugra in Kuwait, which was swollen by Palestinian refugees (from 30,000 in 1948 to 250,000 in 1960). Many other Palestinians ended up in camps or slums elsewhere in Jordan, and in Syria and in Lebanon. The camps on the outskirts of Beirut, Damascus and Amman became virtual quarters of those cities. ${ }^{20}$

In most Arab cities there was a great gulf between rich and poor, particularly the destitute people who migrated from the countryside in search of a meagre living. The plight of such people is dramatized for example through the character of Khaddour in Saad Allah Wannous (1941-1996) masterpiece The Tragedy of the Poor Seller of Molasses (1964). This gap became wider than ever, giving rise to popular movements and mass demonstrations in which students and workers figured prominently. 'With the failure of the social democratic experiment the populace looked for salvation either to the extreme Right (Muslim Brotherhood) or the extreme Left (Marxism)'. ${ }^{21}$ Islam remained a powerful force, and there were modernist attempts to reform the faith that were influential among the educated elite and reflected the discontent many Arabs felt with themselves and their world. Perhaps the writer 'who best expressed the problems and hopes of his generation,22 was Taha Hussein (1889-1973), a blind scholar, historian, novelist and critic, who was committed to the cause of social justice. Hussein is unquestionably one of the most significant intellectual and moral figures of the twentieth century in the Arab world, and was a great influence on al-

\footnotetext{
${ }^{20}$ Ibid., p.386.

${ }^{21}$ M. M. Badawi, A Short History of Modern Arabic Literature (New York: Oxford University Press, 1993), p.15.

${ }^{22}$ Albert Hourani, A History of the Arab Peoples (London: Faber and Faber, 2002), p.341.
} 
Faraj in his later years. ${ }^{23}$ With the rise of the Islamists in the Middle East, Hussein has become the object of attack by conservative religious thinkers. ${ }^{24} \mathrm{Al}$-Faraj himself, was a committed secularist, who never refrained from attacking Islamist themselves, reserving his scorn for narrow-minded or power-hungry clerics, who appear in abundance in his dramatic work and are heavily criticised in his writings.

Leftist politics took two main forms: on the one hand, the al-Qawmien al-Arab (Arab Nationalists) Movement, which had been founded in Lebanon, and which in the mid-1950s amalgamated with a more explicitly socialist party, and, on the other, Nasserism in Egypt. al-Qawmien al-Arab was at first an ideological force only, pursuing intellectual debates about the national identity of the Kuwaitis and their relations with other Arabic-speaking communities; by mid-sixties the movement was almost in full control of Kuwaiti Parliament. Ideologically, it was committed to socialism and secularism, but initially not Marxism. Its Arab nationalist approach meant an uncompromising hostility to Western imperialism in general, and Israel in particular, as the movement took a lead in the formation of anti-Zionist doctrine. ${ }^{25}$ The movement path was on support of the Soviet model, with an emphasis on official ideology and a growing personality cult centred on the leader, whose power was consolidated by the orchestration of praise from the official media. ${ }^{26}$

Al-Faraj, as we have noted, detested the Arab one-party states, and its leadership and attacked it vigorously if not always directly in plays such as Member of Parliament (1985), It's Time (1984), and Home Protector (1985). Al-Faraj's criticism, of course, was not limited to the Arab regimes but was directed at all dictatorships. The state's orchestration of the media is satirised in Home Protector, while the sacrosanct person of the ruler is ridiculed in The Minister's Wife (1979). Nasserism essentially appealed to Arab nationalism and unity. It was a form of 'Arab socialism' whose top-down initiatives involved the public ownership of key sectors including banks and the encouragement of equality of opportunity. Although accused by the Muslim Brothers of implementing secular polices with a veneer of Islam, and by Marxists of an 'unscientific' analysis of social relations, Nasserism had a great influence on the morale of Arabs outside Egypt, partly through the skilful use of press and radio; 'The Voice of the Arabs' was by far the most influential in the Arab world. Until 1967, public life in the Arab countries continued to be dominated by this idea of a socialist, neutralist form of Arab nationalism with Nasser as its leader and symbol. There were ominous signs, however, that Nasserism's claims and pretensions could not be sustain Nasser's leadership had been called into question by the failure of the UAR, and there were clear limits to the common interests of the Arab states.

\footnotetext{
${ }^{23}$ Al-Faraj had read Hussein as a schoolboy, but it was not until much later that he came to fully appreciate the Egyptian thinker's work. Unpublished interview with the Kuwaiti playwright Saad alFaraj in 11-5-2016

24 John L. Esposito, The Oxford Encyclopaedia of the Modern Islamic World (New York: Oxford University Press, 1995) p.148.

${ }^{25}$ See Yezid Sayigh Reconstructing the Paradox: The Arab Nationalist Movement, Armed Struggle, and Palestine, 1951-1966 Middle East Journal Vol. 45, No. 4 (Autumn, 1991), pp.608-629.

${ }^{26}$ Roger Owen, State Power and Politics in the Making of the Modern Middle East (London: Routledge, 1992), p.265.
} 
Other developments disturbed al-Faraj: the Arab unity evident in the support given to Egypt and Syria collapsed almost immediately and the Arab states grew militarily weaker and became disunited, particularly with regard to the Arab-Israeli problem. The gap between rich and poor was growing, and increasing oil wealth led to dependence on external investment. The power and influence of the USA in the region increased, and the infitah opened Arab economies to the West, led to a consumer boom and encouraged the rapid development of the private sector. ${ }^{27}$ Al-Faraj later satirised these developments in his late play On Haman, O Pharaoh (1978). Al-Faraj became depressed, and Custom is Another Nature is a work born of despair. Before Al-Faraj completed the play, President Sadat of Egypt visited Menachem Begin in Israel with a view to opening direct negotiations for peace. The betrayal was too much for Arab World. After this crisis, Al-Faraj seems to have decided that, for the foreseeable future, he would have to abandon his calling as a dramatist. His career as a dramatist seemed to be over, and he withdrew into a silence that was to last for more than half a decade. The mood in Arab World was further darkened by the shock of the Israeli invasion of Lebanon and seizure of Beirut in 1982, events which were to give rise to Member of Parliament. His silence throughout the mid-80s was part of a process of re-reading and contemplating history and of coming to terms with the defeats he and his generation of dramatists had suffered. ${ }^{28}$

As the decade progressed, al-Faraj began to entertain the hope that he might find it possible to return to drama, as he reflected on what he had achieved and failed to achieve. It was necessary to revise his opinions, to reconsider his earlier responses to events and to discard his broken dreams. When he returned to writing drama he attempted - without abandoning history or politics - to free himself from his earlier illusions and turned away from larger political questions to deal with personal courage, integrity and responsibility. For the first time he gave himself a relative freedom to liberate himself from the duty to write only about issues of national or international importance. He turned instead to creating a theatre that explored more intimately the relationship between the individual and society. Abandoning the grand narrative of modernisation and focusing on the personal and private, Al-faraj brought the individual character to centre stage. ${ }^{29}$ Though still an Arab Nationalist, he came to see that his consciously held programme of writing in the service of a political reforms that had proved a vain dream had constrained his potential as a dramatist. Moreover, the focus on collective action had made him neglect the struggles and sufferings of individuals, which he had considered unworthy of serious attention.

In the last phase of his writing career he produced one play, that was stopped at the seventh night by censorship. Custom is Another Nature focuses on socio-political corruption. This play is a transitional work, looking back in some respects to the plays of the 1960s and 1970s, and forward in others to the plays of the mid-1980s. The prospect of growing old impelled him to create a work that challenged convention and taboos in ways unprecedented in his writing. In the play, al-Faraj discovered and gave

\footnotetext{
${ }^{27}$ Albert Hourani, A History of the Arab Peoples (London: Faber and Faber, 2002), pp.422-3, 426, 436.

${ }^{28}$ Unpublished interview with the Kuwaiti critic Dr. Khalid Ramadan in 12-4-2015.

${ }^{29}$ Ibid.
} 
expression to an extraordinary freedom from constraints, in which the treatment of clergymen credibility remains profoundly shocking to many Arabs; even today performances are heavily censored.

Al-Faraj's experiments with form were no less adventurous: in Custom is Another Naturehe employs a complex structure of intersecting voices and narratives, creating a polyphony of different discourses. ${ }^{30}$ The play is based on the suffering of Kuwait on the hands of Islamic forces in the 50's era, using this event to comment on the Islamist growing power in the 80's. It is critical of the extremist scholars, and offers qualified praise to the moderate clerics, who fought and died as martyrs.

The contradictions in the characters and the tensions in their motivations are the substance of the drama and are intended to prompt critical thought in the audience, which is presented with the argument that individuals take no less responsibility in the making of history than nations and governments. ${ }^{31}$ Custom is Another Nature themes are very varied, ranging from savage satire on global capital and the consumer culture to meditations on family history, memory and the relativity of truth. The Kuwaiti critic and playwright Khalid Ramadan (1950 - ), who spent most of his adult life in Kuwaiti theatres, notes, this work is politically and humanly richer and more significant than anything he had written before. ${ }^{32}$ Anti-corruption is a constant theme in this play. In this work Al-Faraj, eschewing all religious or philosophical comfort, confronts his own disappointment in its naked reality.

Censorship plagued the dramatists since the 1960s, and continuous to restrict freedom of expression; indeed, modern Arabic and Arabian Peninsula drama cannot be understood without an understanding of the power of the censor. In the early part of GCC playwrights' career censorship was imposed by governments for political rather than religious reasons, but, as Mostyn notes; «Throughout the Arab world the secular nationalism and Marxism of the 1960s and 70s have given way to Islamic fundamentalism». ${ }^{33}$ This force has had a powerful impact on every aspect of life in the Arab world, drama included. Mostyn further remarks that the 1980s and 90s witnessed a dramatic growth in the influence of political Islam, which has at times become the equivalent of a shadow government, or even the actual government, as in Arab world. ${ }^{34}$ In the later part of their career GCC playwrights became deeply concerned by this trend, seeing it as inimical to their most cherished principles. Their championing of the thought of secularists such as Taha Hussein should be understood in this context. They were right to be concerned: even today their works are unavailable in so many GCC countries, some cannot be performed without cuts. Nevertheless, political censorship continued. ${ }^{35}$

According to al-Faraj, Custom is Another Nature, came at a time, when drama was predominantly a «..mouthpiece [of the people]». ${ }^{36}$ The extraordinary challenge

\footnotetext{
${ }^{30}$ Unpublished interview with the Syrian critic Dr. Nadim Mua'ala in 12-4-2013.

${ }^{31}$ Unpublished interview with the Kuwaiti critic Dr. Khalid Ramadan in 22-4-2015.

32 Ibid.

${ }^{33}$ Trevor Mostyn, Censorship on Islamic Societies (London: Saqi Books, 2002), p.125.

${ }^{34}$ Ibid., p.126.

${ }^{35}$ See Trevor Mostyn, Censorship on Islamic Societies (London: Saqi Books, 2002), p.40.

36 From an interview conducted by al-Hurra TV channel. Seen on 6 June 2017. https://www.youtube.com/watch?v=qHnzL06DVmM.
} 
posed by the play and the debate it immediately engendered alarmed the government. In late 1987, after a few performances the authorities not only banned the play, but the Ministry of information also withdrew the script from sale, thus preventing its printing as well as any further performances. They saw the play as an outrageous instigation, and were not persuaded to reconsider even when he was awarded a prize for committed drama by the Kuwaiti people.

Custom is Another Nature was never reprinted even for academic usage, and never produced ever since, «to avoid censorship». ${ }^{37}$ According to a newspaper report, «The play was very well received in Kuwait [back then], and was shown there for a number of nights». ${ }^{38}$ In Kuwait, this success caught the attention of a number of critics and directors, who requested that the censor lift the ban and permit the play to be performed at The Second Festival of Theatre Arts, to be held the same year. ${ }^{39}$ The authority concerned had already decided to lift the ban on similar works, but quickly went back on its decision after few a days without giving any reason or justification; Khalid Ramadan has commented that «the censors' decisions were often capricious and difficult to fathom». ${ }^{40}$ Mostyn notes that the Arab governments censors had wideranging powers granted them by the 1963 State of Emergency Law; these included censorship of «all means of communication, propaganda and publicity before issue; also their seizure, confiscation and suspicion and the closure of the places in which they are printed». ${ }^{41}$ So Custom is Another Nature and many other similar plays, were a problematic case for the authorities from its earliest days.

In Custom is Another Nature to al-Faraj makes it clear that in order to maintain their power, the regimes must tighten their grip on every significant kind of culture, including theatre, and ensure that their propaganda is disseminated as widely as possible. To do this, they made use of theatrical censorship both directly, by banning plays, as the Syrian Ministry of Culture did - for example - with Evening Party, by Saad Allah Wannous in 1968, and indirectly by encouraging productions such as those presented by the Egyptian National Theatre. Sometimes Arab regimes took more extreme measures than those applied to al-Faraj. We have noted that the Syrian poet Ali Ahmid Said (1903- ) also know by the pen name Adonis or Adunis, was imprisoned in 1956; and in Iraq, and in Egypt, for instance, a playwright, an actor, or even a singer might be persecuted by the security authorities though the fabrication of false evidence and jailed. ${ }^{42}$ The Egyptian secret police used this tactic against playwrights and intellectuals opposing Nasser's rule (1954-1970), on the ground that they were guilty of undermining the 1952 July revolution which had overthrown King Farouq. The eminent journalist Mustafa Amin (1914-1997) was imprisoned in the mid-1960 and tortured by Nasser's jailers for his opposition to the regime. The charge was that he had been spying for the USA. He was released by President Sadat in 1974. Whether direct or indirect, the effect of censorship was to create the anger and grief reflected in Arab's and GCC theatre, and to cause people to reject the state's

\footnotetext{
${ }^{37}$ Ibid.

${ }^{38}$ Unpublished interview with the Egyptian critic Mohamad Hassan 20/1/2010.

${ }^{39}$ See Al-sharq al-Awsat Newspaper, 27 June 2003, p.31.

${ }^{40}$ Unpublished interview with the Egyptian critic Mohamad Hassan 20/1/2010.

${ }^{41}$ Trevor Mostyn, Censorship on Islamic Societies (London: Saqi Books, 2002), p.159.

${ }^{42}$ See Trevor Mostyn, Censorship on Islamic Societies (London: Saqi Books, 2002), p.32.
} 
'ready-made' awareness and the dominance of the single view in those countries where the 'tongues of millions of people are cut off'.

al-Faraj had prepared his actors for the performances of the $6^{\text {th }}$ night, and the dress rehearsal took place a couple of days before the first nights, when the Ministry of Information officials arrived. According to al-Faraj, «In 1987, the rehearsals were going very well. Some officials came, and when we had finished, they said to us 'This play is inappropriate' and told him he would not be allowed to continue presenting it the following evenings. They haven't summoned him later on for any interrogations although they treated him gently. [...] I think the play was banned because of its similarities with the socio-political situation [in the region] back then. al-Faraj was cultured man, and so his plays usually contain a shrewd and perceptive reading of the political situation». ${ }^{43}$ Curiously, censors had already after Kuwait liberation in 1991, removed the ban on Custom is Another Nature; according to al-Faraj, no performances were given ever since. Kuwaiti critic Khalid Ramadan commented, «Censorship in Arab World is unpredictable. You can't say for sure why they released this play and banned that one! ${ }^{44}$ However, it is probable that censors considered these plays banned before 1990 were directed against the old issues and thus could be released for performance, while those written after 1991 could be interpreted as alluding to current situation and therefore should be banned. ${ }^{45}$ But even after 1991 al-Faraj did not present Custom is Another Naturein Kuwait. We do not know why, but it is possible that what the critic Nadim Mua'ala had called the «great achievement $»^{46}$ of the 1991 war against Iraq created a political atmosphere in Kuwait and other GCC countries that made it 'inappropriate' to attack the local affairs. Moreover, the public's reaction would not have been sympathetic; those leaders had, after all, won what the overwhelming majority of GCC peoples considered a historical victory. In any event, as Mua'ala comments, the 1991 war restored GCC self-confidence, «which [had been] lost after the catastrophe od 1990». ${ }^{47}$ Whether or not this was an important factor in al-Faraj thinking, apart from the 1987 production the play remained unperformed in Kuwait. ${ }^{48}$

The censorship is a universal phenomenon, and in this sense al-Faraj is right to claim that the play applies to all class societies. It is not necessarily true, however, that all class societies must rely on ever more terror and repression. Bourgeois democracies have other means of ensuring stability and compliance. Boal remarks in this connection:

[...] the ruling classes pretend kindness and become reformist [...] in the belief that a social being will be less revolutionary to the extent that he is less hungry. And this mechanism works. It is not for any other reason that the working classes in capitalist countries show so little revolutionary spirit, and rather prove to be

43 Ali Husain al-Awadi, 'Interview with Saad al-Faraj', al-Taleea News Paper, 8-7-2015, http://altaleea.com/?p=13344 seen on 10/10/2017.

${ }^{44}$ Unpublished interview with the Syrian critic Dr. Nadim Mua'ala in 12-4-2013.

${ }^{45}$ See same idea at Trevor Mostyn, Censorship on Islamic Societies (London: Saqi Books, 2002), p.84.

${ }^{46}$ Unpublished interview with the Syrian critic Dr. Nadim Mua'ala in 12-4-2013.

${ }^{47}$ Ibid.

${ }^{48}$ The performance was never recorded and no copy placed in the archives of the Kuwaiti Television. It is not generally available and cannot be obtained even by applying to the authorities 
reactionary, like the majority of the proletariat in the United States. They are social beings with refrigerators, cars and houses $[\ldots] .{ }^{49}$

As in al-Faraj case, in 1992 the Syrian left-wing playwright Wannous was interviewed by the American journalist Judith Miller. He told her that Syrian officials tolerated some of his more critical work because it enabled them to show the West that Syrians enjoyed freedom of expression. «My very existence is propaganda», ${ }^{50}$ he explained. He pointed out that the Syrian censors had banned his prominent play, The Rape, and that al-Thawra and Al-Baath newspapers had been barred from publishing his name; like Israel, he was «an abstraction». The regime's displeasure had been aroused by the play's final scene, in which Wannous bring himself to create a sympathetic Jew who believed in Israel's right to exist.

Al-Faraj began to write Custom is Another Nature at the last days of Iran-Iraq War in 1987; Kuwait initially stayed neutral and also tried mediating between Iran and Iraq, yet in 1987, Kuwait (whose tankers were being attacked by the Iranians) asked the US to intervene. Al-Faraj evidently concluded that the situation required that those who had the courage and determination should speak out against the communities that had failed internally and internationally. Like his prophetic character in his earlier play Kuwait in 2000, al-Faraj did not shrink from speaking what he believed to be the truth about the troubled reality in Arab world, and its causes, but to do so in a new way. Custom is Another Nature deals with that bitter reality in a way that was unprecedented in the theatre of Kuwait; Al-Faraj's method is now one of direct attack and loud denunciation of the totalitarian regimes, condemning their dictatorial methods and monopoly of power.

The catastrophic impact of the of Iran-Iraq War caused al-Faraj to change his approach to playwriting. In 2017, at a time when he had abandoned writing for the theatre, he explained the nature of that change to the Kuwaiti critic Ali al-Anezi. Now, more than 25 years later, unsure of the future of Arabic drama, his words were bitter:

When I started writing Custom is Another Nature, I wanted to convey the meaninglessness of writing and the emptiness of words. What is the use of words when deeds are what we need in order to cleanse us of words' rottenness and falsehood, of their stench spreading in the scorching heat of the Wars? What is the use of words if they do not match our deeds? ${ }^{51}$

Al-Faraj deplored the condition of his nation and strove to find a solution. He was to find it, at least for a time, in the committed theatre. Al-Faraj later said:

After the first Gulf War, the battle to create a relationship between theatre and politics was a pressing issue. It was clear that the theatre, like the Arab people, was

\footnotetext{
${ }^{49}$ Augusto Boal, Theater of the Oppressed, translated by Charles A., Maria-Odilia Leal McBride and Emily Fryer (London: Pluto Press, 2000), p.97. For a description of the operation of this mechanism in Saudi Arabia see Trevor Mostyn, Censorship on Islamic Societies (London: Saqi Books, 2002), pp.40-41.

50 Judith Miller, God Has Ninety-Nine Names (New York: Simon and Schuster, 1996), p.317. In Trevor Mostyn, Censorship on Islamic Societies (London: Saqi Books, 2002), p.40.

${ }^{51}$ Unpublished interview with the Kuwaiti playwright Saad al-Faraj in 11-5-2016
} 
taken by surprise by the wars, and it had been too late in responding to the pressing issues. It seems that because of negligence and other complex cultural problems in which the ruling regimes had a hand, the theatre had not found time to tackle these questions and answer them properly; it became clear that it had been an instrument of deception or a part of a great cultural campaign of misinformation. ${ }^{52}$

It seemed to al-Faraj that the wars had dealt a fatal blow to his earlier works; it had also unmasked the dreams that Arab leaders, had peddled in their public addresses. The playwright began to fashion his pen into a surgical instrument, anatomising the anaesthetised regional body, hoping that his theatre would be a catalyst in bringing about change. For al-Faraj, the Arab Wars was not simply a bitter military defeat; rather it was a natural consequence of the power monopoly and corruption that characterised the dictatorial regimes, as well as a direct reflection of the internal defeat of the ordinary citizen brought about by the moral and often physical torture he had experienced daily at the hands of such regimes. Al-Faraj had addressed the nature of this internal defeat though the character of Bu Migbil in Custom is Another Nature. For him, the defeat revealed the true nature of the relationship between the ruling regimes and the people, evident in the removal of the ordinary citizen from the decision-making process. It revealed also the potential importance of what he termed later 'the enlightenment of the Arab people' through a 'political theatre', that would urge them to recapture their social and political rights, stolen by the totalitarian regimes that ruled them with an iron fist. As he explained in 2017, Custom is Another Nature was written under the pressure of the absurd wars, in an atmosphere of depression and frustration and from a desire to bring about enlightenment. It was a matter of urgency not only to reflect the existing state of affairs but also to try to describe reality in such a way that would open other horizons and allow us to seize a better future'. ${ }^{53}$

At first al-Faraj found himself unable to respond to the Arab Wars. In 1983 he vividly described his struggle with the impulse to abandon writing altogether: 'Following the wars, as a scattered Arab nationalist, I wondered, why do we write? The question was like swallowing a bundle of thorns' ${ }^{54}$ However, when he returned to his work in the spring of 1985 he found that the vitality of the capital's intellectual and cultural life gave him the energy to begin to write again. He determined to eschew what he now saw as equivocation and nightmarish distractions, by radically reconsidering and going beyond his early theatre. Of this new mood he later wrote, 'The wars was so bitter that it created a [new] kind of awareness'. ${ }^{55}$ This awareness produced perhaps al-Faraj 's most famous work; these were bold statements challenging the dictatorial regimes in the Arab world in general which in that respect have had few rivals in Kuwait. He produced five plays over the next decade: Evening Party (1967-1968), The King's Elephant (1969), The Adventure of the Slave Jabir's Head (1970), Soirée with Abu Khaleel al-Qabani (1972) and, after a gap of five years,

\footnotetext{
${ }^{52}$ Ibid.

${ }^{53}$ Ibid.

54 Ibid.

55 Ali Husain al-Awadi, 'Interview with Saad al-Faraj', al-Taleea News Paper, 8-7-2015, http://altaleea.com/?p=13344 seen on 10/10/2017.
} 
The King's the King (1977). In these works he reconsidered the relationship between theatre and politics, using the theatre as an instrument to unmask corruption and as a mirror to reflect the real situation in the Arab countries as he saw it. In 1970 al-Faraj wrote, 'We create a theatre because we want to change and develop the people's mentality and to deepen our collective awareness of our common historical destiny'. ${ }^{1}$ He later argued that when 'people are given the chance to express themselves and learn how to make their voices heard, they will gradually come to possess the boldness necessary for making a true statement and thus shattering the internal power that has seized their destiny'. ${ }^{2}$ Al-Faraj emphasised that after the mid-1960s he sought sought a theatrical form, controlled by the people rather than controlling them, which would be 'active'; that is, which would lead to a revolt against the existing reality. 'I said to myself, why don't we start from the status quo [...] why don't we work out a theatre that is suitable for us? From this came Custom is Another Nature [...]'. ${ }^{3} \mathrm{He}$ had

a conviction that culture in general and theatre in particular were being methodically marginalised by the totalitarian Arab regimes, and he believed that the role of the theatre was to serve the downtrodden members of society, especially the peasants and working class, whom al-Faraj called 'the lower-class citizens' ${ }^{4}$ In other words, it should serve the transformation of society by acting as a catalyst of serious action.

At first al-Faraj found himself unable to respond to the Arab Wars. In 2017 he vividly described his struggle with the impulse to abandon writing altogether: 'Following the wars, as a scattered Arab nationalist, I wondered, why do we write? The question was like swallowing a bundle of thorns'. ${ }^{5}$ However, when «The vitality of the Kuwaiti's intellectual and cultural life gave me the energy to begin to write again». ${ }^{6}$ He determined through Custom is Another Nature to eschew what he now saw as equivocation and nightmarish distractions, by radically reconsidering and going beyond his early theatre. Of this new mood he later wrote, 'The wars was so bitter that it created a [new] kind of awareness'. ${ }^{7}$ This awareness produced perhaps al-Faraj 's most famous work, i.e. Custom is Another. In these work he reconsidered the relationship between theatre and politics, using the theatre as an instrument to unmask corruption and as a mirror to reflect the real situation in the Arab countries as he saw it. In 2017 al-Faraj said, 'We create a theatre because we want to change and develop the people's mentality and to deepen our collective awareness of our common historical destiny, ${ }^{8}$ He later argued that when 'people are given the chance to express themselves and learn how to make their voices heard, they will gradually come to possess the boldness necessary for making a true statement and thus shattering the internal power that has seized their destiny'. ${ }^{9}$ Al-Faraj emphasised that

\footnotetext{
${ }^{1}$ Ibid.

${ }^{2}$ Unpublished interview with the Kuwaiti playwright Saad al-Faraj in 11-5-2016

${ }^{3}$ Saad al-Faraj, Custom is Another Nature, unpublished copy of the play.

${ }^{4}$ Ibid.

${ }^{5}$ Unpublished interview with the Kuwaiti playwright Saad al-Faraj in 11-5-2016

${ }^{6}$ Ibid.

${ }^{7}$ Ibid.

${ }^{8}$ Ibid.

${ }^{9}$ Ibid.
} 
after the mid-1980s he sought a theatrical form, controlled by the people rather than controlling them, which would be 'active'; that is, which would lead to disapprove the existing reality. 'I said to myself, why don't we start from the status quo [...] why don't we work out a theatre that is suitable for us? From this came Custom is Another Nature $[. .$.$] '. { }^{1}$ He had a conviction that culture in general and theatre in particular were being methodically marginalised by the totalitarian Arab regimes, and he believed that the role of the theatre was to serve the downtrodden members of society, especially the working class and peasants, whom Al-Faraj called 'the lower-class citizens'. ${ }^{2}$ In other words, it should serve the development of society by acting as a catalyst of serious steps.

Custom is Another Nature was al-Faraj 's first and last work to reflect this new programme. Khalid Ramadan, remarked, 'When I saw Custom is Another Nature's first performances [in Kuwait] I felt so happy in spite of the grim regional conditions of that time. I was glad because this was the first time that a GCC playwright had stood firm in that difficult time to confront the truth in all its severity and harshness'. ${ }^{3}$ The play achieved immediate fame and remains highly regarded among Kuwaiti intellectuals. No other Kuwaiti play of the late 1980s has achieved such a reputation, which is founded upon several important features. First, as Khalid Ramadan ${ }^{4}$ points out, the extent of al-Faraj's use of Brecht's techniques in combination makes the work a pivotal event within the context of Kuwaiti drama of the time. These techniques are the direct address to the audience and the changing of stage settings in full view of the audience by actors or theatre workers. Al-Faraj also achieves a distancing effect by placing actors among the audience. Custom is Another Nature was not the first Kuwaiti play to use Brechtian techniques. As Khalid Ramadan points out, in Kuwait Abdul Ameer al-Turky's Hami al-Diar (Homes' Protector, 1985) employed such techniques, ${ }^{5}$ but al-Faraj was the first Kuwaiti playwright to use them in an attempt to generate political action among the audience. ${ }^{6}$ Second, Custom is Another Nature was one of the rare Kuwaiti plays to draw a demarcation line between two periods. It discards the sensationalism and empty nationalist slogans that had predominated in the 1960s and 1970s, and attempts to anatomise the conditions prevailing in the region in order to disclose the real causes of the soar status quo. Third, and perhaps most importantly, in addition to its enlightenment purpose, it also called for a change in the function of theatre, and its role in serving society. Shortly after writing the play, al-Faraj said, 'I want a theatre that teaches and that inspires to development, challenges the audience, provokes them, pushes them to ask the question: 'why [are things as they are]?. ${ }^{7}$ This naïve and unrealistic hope, partly fired by al-Faraj 's experiences in Arab Wars, was doomed to fail in the very different conditions of the Arab world.

\footnotetext{
${ }^{1}$ Ibid.

${ }^{2}$ Ibid.

${ }^{3}$ Unpublished interview with the Kuwaiti critic Dr. Khalid Ramadan in 22-4-2015.

${ }^{4}$ Ibid.

${ }^{5}$ Ibid.

${ }^{6}$ Ibid.

${ }^{7}$ Unpublished interview with the Kuwaiti playwright Saad al-Faraj in 11-5-2016.
} 
Al-Faraj's distress at the regional conditions was different from the helpless passive sorrow felt by many; it was, as Ramadan has said, 'critical and analytical'. ${ }^{1}$ He attempted to translate his disillusionment and anger into words through which lessons could be learned. It proved not to be an easy task. The new work would have to be very different from his previous works if it was to fulfil al-Faraj's purposes. In 2016 al-Faraj surprisingly said, in an interview with the author, that Custom is Another Nature was not first and foremost a theatrical work. Al-Faraj explained, 'It was a risk taken in a troubled region which had been hard hit by this historical chaos'. ${ }^{2}$ Once al-Faraj had overcome his dejection he found that the surroundings had created an enthusiasm in him different from that apparent in his earlier works. He had become acutely aware of the importance of 'words' and their role in promoting and clarifying his society's political awareness. In al-Faraj's view, it was impossible after the all these Arab wars to continue to indulge in experimentation for its own sake, only hinting at meanings and allowing the audience to read between the lines; rather it was necessary to destroy the ideological structure and to reconstruct it from scratch in such a way that it conformed to the time's significant events, and to the interests of the deprived people in Arab World society. What was needed was a 'different ambition', as he put it in 2016, that would enable the theatre to fulfil its social function. He explained this in his terms in his conversation with author:

In the mid-eighties, the relationship between me and 'words' began to become very clear, as if under a spotlight. Now I can understand the relationship; it involved a different ambition: to reveal the collapse of reality by means of words and to engage in a direct struggle that would change the existing state of affairs. The role of a mere witness could not be truly effective, which I intended to be. ${ }^{3}$

Al-Faraj believed that such a 'different ambition' could be made to change history, through decisive effect on the spectator. Al-Faraj's audiences, would be moved to transform themselves from passive observers of events into an 'active' party - a collectively - that would take their destiny into their own hands. al-Faraj believed that what was needed was a '[...] theatrical movement that continuously interacts with its audiences [...] A theatrical movement of this kind is capable of leading the theatre out of its labyrinth'. ${ }^{4}$ This transformation of the audience's consciousness was to be achieved by creating a new relationship between the audience and the actor. That relationship was founded upon the conviction that the ambiguities that had dissipated the theatre's energies had been swept away by the Arab Wars. al-Faraj's new 'awareness' was based on his certainty that a scientific analysis of conditions in the Arab world would enable the theatre to decisively intervene in history. Nadim Mua'ala has pointed out that the 'question of theatre' in the late 1960s and 1970s was not so much what the truth is, but how this truth could

\footnotetext{
${ }^{1}$ Unpublished interview with the Kuwaiti critic Dr. Khalid Ramadan in 22-4-2015.

${ }^{2}$ Unpublished interview with the Kuwaiti playwright Saad al-Faraj in 11-5-2016

${ }^{3}$ Ibid.

${ }^{4}$ Ibid.
} 
be brought to the stage and presented to the audience in such a way as to offer no room for doubt. ${ }^{1}$

It should be remembered that the general situation in the region allowed the entertainment of the hope that 'change' could sweep away corruption and the corrupted. Many groupings, from the Marxists on the left to the Muslim Brotherhood on the right, believed that the despotic Arab states, weakened by the defeat, could be overthrown by the people - as long as the people were properly led and guided. Belief in the 'inevitable' collapse of the existing order was not confined to the Arab countries: Europe and the USA were also shaken previously by powerful political disturbances that seemed to some to be the heralds of profound social transformation, linked by a shared international consciousness of the need for radical reform. Street protests were occurring in Germany, where there had been a wave of student agitation against the university system; in Spain where from October 1967 to June 1968 students organised street demonstrations for freedom of the press and against the Franco regime; in Italy, where students campaigned in Rome, Pisa, Turin and Milan for reforms of the university system; in Poland, where students were in the forefront of the liberalisation movement in the period later to be known as the Prague Spring. 'A wind of freedom had swept across Europe and had taken to cosmopolitan Paris all the seeds of revolt it had gathered from different parts of the continent. And in Paris, these seeds found their most fertile ground yet'. ${ }^{2}$ The 'May events' of 1967 almost brought down the French government. al-Faraj was studying in England in that turbulent era, and was apparently exhilarated by the ferment taking place in the capital of the old colonial power.

We know nothing concrete about the gestation of Custom is Another Nature but it seems reasonable to assume that the regional catastrophes and al-Faraj's newly kindled interest in Brecht had a direct effect on the play's final form. al-Faraj was also reacting strongly against the dominant trends in the 'official' theatre of the Arab world. In Kuwait, all the major theatres were under the supervision of the governmental censor, which, according to al-Faraj, found it desirable to use the theatre only to disseminate culture 'by presenting random and irrelevant examples from the repertoire of world theatre'. ${ }^{3} \mathrm{Al}$-Faraj sarcastically noted that even after the disaster of 1967 Arab theatrical productions continued to present 'entertainments [...] where the popular troupes performed their folk dances and concerts' ${ }^{4}$ to glorify the military governments. The repertoire of the main state theatre, The National Theatre, was controlled by the government, and it was also the place to be seen, where the aristocracy and bourgeoisie rubbed shoulders with the compliant theatre-going intelligentsia. The Syrian critic Nadim Mua'la observed in 1988 that 'the national theatre was tailored to its audience; that is, the Arab bourgeoisie'. ${ }^{5}$ Thus the Arab theatre attempted to be a cultural ornament, presenting examples of world theatre or panegyrics to the regime and showed nothing al-Faraj considered relevant to Arab

\footnotetext{
${ }^{1}$ Unpublished interview with the Syrian critic Dr. Nadim Mua’ala in 12-4-2013.

${ }^{2}$ Marc Rohan, Paris '68: Graffiti, Posters, Newspapers \& Poems of the May 1968 (Great Britain: Impact Books, 1988), p.22.

${ }^{3}$ Unpublished interview with the Kuwaiti playwright Saad al-Faraj in 11-5-2016.

${ }^{4}$ Ibid.

${ }^{5}$ Unpublished interview with the Syrian critic Dr. Nadim Mua’ala in 12-4-2013.
} 
life. Al-Faraj commented that its 'main concern [...] was to tailor its activity to the identity and needs of its audience', ${ }^{1}$ and he decided to oppose the governmentsponsored theatre, which deliberately ignored the 'third-class citizens'. Before Custom is Another Nature, some writers had commented critically on the political situation, although such comments were very rare, and they were concealed, similarly to those in al-Faraj's early works, under symbolism and ambiguity in order to escape the attentions of the authorities. The case of Custom is Another Nature is totally different, because al-Faraj was determined to confront the misdeeds and failings, and to issue a challenge to censors, no matter what the consequences.

The novelty of the work. For the first time, comprehensively and using political methodology and drawing on an art-study analysis, the activities of theatres in Kuwait in the second half of the twentieth century have been explored. The scientific circle introduces important information about the creative work of Sa'ad al-Faraj, which is carried out an art-study analysis of his play «Tradition is another nature.»

Conclusions. The catastrophe of Arab wars awake al-Faraj to the need for a new kind of drama, but he was unable to respond to the challenge of the defeat until he Custom is Another Nature. The political status que provided the stimulation he needed to begin work on what was to become Custom is Another Nature, the first of his avowedly political plays and the work which initiated his theatre of politicisation. In particular, the events of the Six-Days War were to prove hugely influential on his thinking, since they appeared to show that a country could be brought to the brink of disaster in six days, and that all political and cultural institutions could be challenged. It was during this period of ferment that al-Faraj felt moved to join a political group for the first and only time in his life. Custom is Another Nature marked a radical departure from his earlier concerns. In seeking to diagnose and dramatize the causes of the defeat, Custom is Another Nature directly attack the despotic regimes he saw as responsible for the weakness and disunity of the Arab world. Dramaturgically, the play reflects al-Faraj's newly kindled interest in the theatre of Bertolt Brecht and is dependent for its effect on the construction of a strong and direct relationship between stage and auditorium. This relationship, al-Faraj hoped, would create an interaction between actors and audience that would incite the latter to take direct political action against the region's regimes, eventually securing the return of Arab dignity to its exiled citizens. The play stresses the importance of collective action and, by implication, the unimportance of the individual in social transformation. Custom is Another Nature was also a cultural call to arms against the region's governmentsponsored theatres and their stupefying propaganda.

\section{Bibliography}

Al Souleman, Ali, 2005. From Staging the World to Staging the Self: Sa'dall ah Wann us and the Question of Theatre (Unpublished thesis). Oxford University.

Al-Awadi, Ali Husain, 2015. 'Interview with Saad al-Faraj', al-Taleea News Paper, 08 july 2015. [online] Available at: $<$ http://altaleea.com/?p=13344> [Accessed 10 October 2017].

${ }^{1}$ Ibid., p.51. 
Al-Faraj,Saad, 1965. Hatha Sefoh - Custom is Another Nature. 1987. [Unpublished copy of the play]. Al-Shaa'bi Theatre archive.

Al-Faraj,Saad, 1965. Kuwait Sanat 2000 - Kuwait 2000. [Unpublished copy of the play]. AlShaa'bi Theatre archive.

Al-Faraj, Saad, 2016. Unpublished interview with by the Author, 11 May 2016.

Allen, R., 2000. An Introduction To Arabic Literature. United Kingdom: Cambridge University Press.

Alsharq al-Awsat, 27 June 2003, p.31.

Al-Tahir, Ahmid, 1997. The War of June 1967. Cairo: Al-Ahram Centre for Translation and Publishing.

Badawi, M.M., 1993. A Short History of Modern Arabic Literature. New York: Oxford University Press.

Boal, Augusto, 2000. Theatre of the Oppressed. Translated by Charles A., Maria-Odilia Leal McBride and Emily Fryer. London: Pluto Press.

Esposito, John, 1995. The Oxford Encyclopaedia of the Modern Islamic World. New York; Oxford: Oxford University Press.

Mohamad, Hassan, 2010. Unpublished interview with by the Author, 20 January 2010.

Hourani, Albert, 2002. A History of the Arab Peoples. London: Faber and Faber.

Interview conducted by al-Hurra TV channel. Seen on 6 June 2017. [online] Available at: https://www.youtube.com/watch?v=qHnzL06DVmM [Accessed 10 October 2017].

Miller, Judith, 1996. God Has Ninety-Nine Names. New York: Simon and Schuster.

Mostyn, Trevor, 2002. Censorship in Islamic Societies. London: Sagi Books.

Mua’ala, Nadim, 2013. Unpublished interview with by the Author, 12 April 2013.

Owen, Roger, 1992. State Power and Politics in the Making of the Modern Middle East. London: Routledge.

Ramadan, Khalid, 2015. Unpublished interview with by the Author, 22 April 2015.

Rohan, Marc, 1988. Paris '68: Graffiti, Posters, Newspapers \& Poems of the May 1968. Great Britain: Impact Books.

Yezid, Sayigh, 1991. Reconstructing the Paradox: The Arab Nationalist Movement, Armed Struggle, and Palestine, 1951-1966. Middle East Journal, 45, 4 (Autumn, 1991), pp.608629.[online] Available at: <https://www.jstor.org/stable/4328352?seq=1\# page_scan_tab_contents> [Accessed 10 October 2017].

$\overline{\text { (C) Al-Anezi A., } 2018}$ 
Аль-Анезі Алі,

доктор філософії в галузі критики та літератури, доцент, Вищий інститут драматичного мистеитва, Ель-Кувейт, Кувейт

\title{
ДРАМАТУРГІЯ СААД АЛЬ-ФАРАДЖА \\ В КОНТЕКСТІ РОЗВИТКУ ТЕАТРАЛЬНОЇ СПРАВИ В КУВЕЙТІ ДРУГОЇ ПОЛОВИНИ ХХ СТОЛІТТЯ
}

\begin{abstract}
Метою статті $є$ дослідження діяльності театрів Кувейту загалом та інтерпретації на їхніх сценах сучасної арабської драматургії зокрема на тлі політичних подій на Близькому Сходу в другій половині XX ст. Основну увагу автор зосереджує на творчому доробку Саада аль-Фараджа - відомого в Кувейті актора, театрального діяча, драматурга, громадського діяча. Дослідник фокусується на політичних обставинах, що обумовили актуалізацію окремих тем, які порушує в своїх п’єсах Саад аль-Фараджа, аналізує те, як протистояння між Ізраїлем та арабським світом, політика президента Єгипту Гамаля Абделя Насера вплинула на умогляди творчої інтелігенції Кувейту. Суттєвою для автора статті є проблема політичної цензури в сучасному Кувейті, що обумовила короткочасність сценічного життя низки п’єс Саад аль-Фараджа. Значна частина розвідки присвячена особливостям поетики драматургії Саад аль-Фараджа. У період свого творчого становлення митець перебував під значним впливом європейських новаторських течій ХХ ст., що значною мірою вплинуло на художньообразний світ його текстів. Головну увагу дослідник зосереджує на п’єсі Саад альФараджа «Традиція - інша природа», у якій виразно проступають прийоми епічного театру Бертольда Брехта. Методологія дослідження полягає в застосуванні політології 3 метою якнайповнішого розкриття суспільного контексту діяльності театрів Кувейта і творчості драматурга Саад аль-Фараджа. Уводячи творчість кувейтського драматурга у світовий контекст, автор базується на системно-структурному й порівняльному методах. У розгляді конкретного драматургічного твору суттєвим було використання театрально-критичного аналізу. Новизна роботи. Уперше комплексно i 3 використанням політологічної методології на основі мистецтвознавчого аналізу досліджено діяльність театрів у Кувейті в другій половині XX ст. У науковий обіг уводиться важлива інформація про творчий доробок Саад аль-Фараджа, здійснено мистецтвознавчий аналіз його п’єси «Традиція - інша природа». Висновки. Виявлено, що в Кувейті всі основні театри перебували під наглядом урядової цензури, яка, за спостереженнями аль-Фараджа, вважала за потрібне використовувати театр лише для поширення культури «шляхом представлення випадкових та невідповідних прикладів з репертуару світового театру».
\end{abstract}

Ключові слова: арабська драматургія; мусульманські світи; незалежність Кувейту; політичні обставини. 
Аль-Анези Али,

доктор философии в области критики и литературы, доиент, Высиий институт драматического искусства, Эль-Кувейт, Кувейт

\section{ДРАМАТУРГИЯ СААД АЛЬ-ФАРАДЖА \\ В КОНТЕКСТЕ РАЗВИТИЯ ТЕАТРАЛЬНОГО ДЕЛА В КУВЕЙТЕ ВТОРОЙ ПОЛОВИНЫ ХХ ВЕКА}

Целью статьи является исследование деятельности театров Кувейта в целом и интерпретации на их сценах современной арабской драматургии в частности на фоне политических событий на Ближнем Востоке во второй половине XX в. Основное внимание автор сосредотачивает на творчестве Саада аль-Фараджа - известного в Кувейте актера, театрального деятеля, драматурга, общественного деятеля. Исследователь фокусируется на политических обстоятельствах, обусловивших актуализацию отдельных тем, которые затрагивает в своих пьесах Саад аль-Фараджа, анализирует то, как противостояние между Израилем и арабским миром, политика президента Египта Гамаля Абделя Насера повлияла на умозрения творческой интеллигенции Кувейта. Существенным для автора статьи является проблема политической цензуры в современном Кувейте, обусловившей кратковременность сценической жизни ряда пьес Саад аль-Фараджа. Значительная часть разведки посвящена особенностям поэтики драматургии Саад аль-Фараджа. В период своего творческого становления художник находился под значительным влиянием европейских новаторских течений $\mathrm{XX}$ в. и это в значительной степени повлияло на художественно-образный мир его текстов. Главное внимания исследователь сосредотачивает на пьесе Саад аль-Фараджа «Традиция - другая природа», в которой явственно проступают приемы эпического театра Бертольда Брехта. Методология исследования заключается в применении политологии с целью наиболее полного раскрытия общественного контекста деятельности театров Кувейта и творчества драматурга Саад аль-Фараджа. Вводя творчество кувейтского драматурга в мировой контекст, автор базируется на системно-структурном и сравнительном методах. В рассмотрении конкретного драматургического произведения существенным было использование театрально-критического анализа. Новизна работы. Впервые комплексно с использованием политологической методологии на основе искусствоведческого анализа исследовано деятельность театров в Кувейте во второй половине XX в. В научный оборот вводится важная информация о творчество Саад альФараджа, осуществлено искусствоведческий анализ его пьесы «Традиция - другая природа». Выводы. Выявлено, что в Кувейте все основные театры находились под контролем правительственной цензуры, которая, по наблюдениям аль-Фараджа, считала нужным использовать театр только для распространения культуры «путем представления случайных и неподходящих примеров из репертуара мирового театра».

Ключевые слова: арабская драматургия; мусульманские миры; независимость Кувейта; политические обстоятельства. 